\title{
Social Interaction Mechanisms of Exported Turkish TV Series: The Case of Croatia
}

\author{
M. Sami Okumus
}

Radio Television and Cinema Department, Faculty of Communication, Marmara University, Turkey

\section{ARTICLE INFO}

Keywords:

Turkish TV Series

Television

TV Series Production

Exporting Series

Broadcasting Series

Turkey

Croatia

\begin{abstract}
Television series are among the most important television products and are indispensable as prime-time representatives of a broadcast generation that international television channels put a strong emphasis on. Both the quality of the content and the cultural similarities the audience perceives in the story carry relevance in terms of reaching the target audience. This study aims to deal with the development of the TV series sector in the context of Turkish TV series (TTS) in recent years, regarding the export of these series abroad and the sociological and cultural effects of these series in the countries they are shown. The study explores the viewing habits of Croatian viewers, their perspective on television watching, TV series in general, their experience with different TV series and the elements that drew them to continue watching, and their opinion on TV series imported from North America, Latin America, and Europe. The study tries to understand the audience's perspectives on Turkish TV series and how they shape their preferences. This study also presents the number of Turkish TV series released in Croatia between 2010 (when the first Turkish TV series was released in Croatia) and 2020 and their effects on local people. Turkish TV series, production details, and broadcasting info were analyzed and explained using information obtained from the Croatian audience through an online questionnaire.
\end{abstract}

\section{Introduction}

Television series have a pivotal role in the media industry and they are fast becoming a key instrument in the last decade thanks to increasing technological developments. Because of these technical improvements, TV series have emerged as powerful platforms for audiences by their demands. In many countries of the world, audiences can have the opportunity to watch both their own local TV series and many other TV series exported from different countries via their own local television channels or online platforms through their subscriptions. It is now well established from a variety of studies, that TV series are producing in many different subjects and in an almost limitless way as content.

TV series are a major area of interest within the field of television and media industry and they have been studied by many researchers since the 1970s. Nowadays, the area of TV series is increasingly important for researchers because of the increasing worldwide usage of the internet. Contemporary developments in the field of TV series have led to a renewed interest

\footnotetext{
This article is an improved and detailed version of a study presented -online- in ' $7^{\text {th }}$ International Conference on Research in Behavioral and Social Sciences' (ICRBS) in Amsterdam (Netherlands) on October 25, 2020.

* Corresponding author E-mail address: sami.okumus@marmara.edu.tr
} 
in TV series again for any kind of audience. In the past especially ten years increasingly rapid advances in the field of TV series and media have been seen in the light of recent events, the decrease in the cost of TV series due to technological advancements, and the increase in the opportunities to export TV series abroad. TV series can play an important role in addressing the issue of audiences' perceptions and this is very important for a wide range of scientific and industrial processes.

In this context, mass media platforms (Netflix, Amazon Prime, Apple, TV channels and etc.) can analyze their users who log in with their username and password through their systems and also by rating results. However, individual researchers meet the audience only via face to face meetings or questionnaire. The difficulty of accessing information that can be obtained from channels or platforms -within the scope of user information confidentiality- will bring a different perspective to the studies.

Studies of TTS projects show the importance of audience expectations and the business benefits it brings to companies and countries. Data from several studies suggest that TV series encourage people to travel, and help them discover new places and cultures, and learn languages (Çakır, 2013 \& Guzel and Aktas, 2016 \& Matar, 2017 and Abisheva, 2019). Due to this situation, recently, researchers have shown an increased interest in these TTS shown throughout the world.

For this study, questions have been raised about the highly increasing consumption of TTS in Croatia. The issue has grown importantly in the light of Croatia who aired the forty-fifth TTS on its local TV channels in the last decade.

Most studies in the field of TV series have only focused on internet series and other countries' TV series but Turkey. Previously published studies are limited to some small groups and also related to other countries except Croatia. Most studies in TTS have only been carried out in a small number of areas and countries (Greece (2013 and 2018), Georgia (2014), Jordan (2015), Kosovo (2017), Saudi Arabia (2017), Qatar (2017), Pakistan (2017 and 2020), Kazakhstan (2017 and 2019), Algeria (2018 and 2019), Chile (2019), Macedonia (2019 and 2020) and Serbia (2020).

As mentioned above, there are some published data on TTS in the literature and surprisingly, there is no previous study investigating TTS in Croatia. The importance and originality of this work are that it explains the discovery of TTS in Croatia in the last decade and their increasing consumption over the years. This study provides new insights into Croatia about understanding the reasons for the consumption of TTS in the last decade. Because of this reason, this study aims to contribute to the literature as the first study conducted on behalf of Croatian and TTS in this field.

The study generally attempts to show the effects of TTS on the Croatian audience and the expectations of Croats from TTS. The main aim of this study is to explore the relationship between Turks and Croats within the framework of sociological and cultural similarities to determine the reasons why Croats prefer to watch TTS. Research takes the form of a case study in Croatian people who watches TTS and seeks to explain the development of TTS in Croatia in the last ten years.

In this sense, one of the most important events of the 2010s was releasing the ' 1001 Nights' TV series in Croatia (RTL). In the following years, there has been an increasing interest in TTS. The last decade has seen a growing trend towards TTS.

\footnotetext{
${ }^{1}$ The first exported tv series from Turkey to Croatia and its released channel is RTL Hrvatska. The TV series '1001 Nights', which started broadcasting in one of the channels within the Central European Media Enterprises (CEME) in Slovakia (as in Croatia in 2010), was very popular and broke viewer records one after another. A group named Kissuck shot a clip for their song called 'Another One Kid' with the models of Berguzar Korel and Halit Ergenc, the leading actors of ' 1001 Nights'. This situation, which can be considered as a clear example of the cultural circulation of the success of Turkish TV series, and also proves that culture was perceived as a distant or even enemy until a
} 
The research data in this study is drawn from four main sources. After the introduction part, the first section of this study will explain the situation about TTS in the world and Croatia as a summary. The second section will contain detailed information about the developments in Croatia on behalf of TTS. The third chapter is concerned with the methodology used for this study and chapter four as a final will analyze the results of surveys and discussions undertaken during the research.

Qualitative and quantitative research designs were adopted to provide information that is useful and necessary for this study. The study was conducted in the form of a survey, with data being gathered via Google Survey.

The hypothesis of this study is the assumption that there are cultural, sociological, and philological similarities between Croats and Turks, who have been following and watching with great interest since the first TTS was broadcasted in Croatia.

In this respect, the present study provides the first comprehensive evaluation of Croatia and TTS. It is hoped that this research will combine to a deeper understanding of Croatia and TTS in this way and make a great contribution to future researches.

\section{Turkish Television Series in the World and Croatia}

This section has been used to understand the current situation and place of the developing TV series industry in the world and Croatia, as well as the point the TTS has reached in recent years and how important it is in audience demands.

Nowadays the TV series which are, among other television products, seriously demanded by the audience are highly important for producers and countries. It can reach audiences all over the world with satellites and internet connections easily. Currently, dozens of TV series are being produced and broadcasted under the title of many genres by producers and television channels to the audience.

Through its regional and economic power, Turkey has become a rising power in the world. With that rising reputation, other countries wishing to familiarize themselves show increased demand for TV series in order to find the shortest path (Gumus, Zhaxyglova, and Mirzabekova, 2017: 395).

The worldwide success of TTS has economic, cultural, and sociological impacts for Turkey, and also for other countries. In the context of today's cultural imperialism, Turkey has become the second most exporting countries in the world. So, there is a unique opportunity to spread Turkey's culture and values ${ }^{1}$ all over the world (Aslan, 2019: 27 and Sputniknews, Sep 16, 2019). The number of exports was nearly fifty countries in 2012. In the article published on variety.com in the USA, it was noted that the Turkish series sector continued to grow. In Turkey, the number of exported TV series began to grow in 2008 and the financial transactions of the exported TTS which were ten million dollars in the same year ${ }^{2}$ reached three hundred and fifty million dollars in 2016. It is known that this spread reached one hundred forty-two countries of the world ${ }^{3}$ and ranked second after America in exports (Hurriyet, Apr 4, 2017, and Variety, Apr 1, 2016).

few years ago was seen as close and "from us" in a few years (Aslan, 2019: 34). In the same year, the commercial film was shot with Halit Ergenc and his wife Berguzar Korel for 'Konzum', one of the biggest shopping chain brands in Croatia, after the sequel of '1001 Nights', which was published in 2010 (Youtube, Dec 7, 2010). On the other hand, "Bulgaria imported twenty-seven different Turkish series such as 'Binbir Gece' and 'Yaprak Dökümü' in 2010 and became the second country to which Turkey exported TV series in 2011 as Sofia Press Agency reported from the Bulgarian National Radio" (Retrieved from Agirseven \& Örki, 2017: 848).

${ }^{1}$ As Aydin and Deniz stated (2010) "between 2005 and 2011 a total of 35,675 hours of Turkish TV programs were sold to 76 countries around the world. Among the TV program exports, there have been 65 soap operas, which have generated an income 60 million dollars" (Yörük \& Vatikiotis, 2013: 2362).

${ }^{2}$ According to data in 'www.forum.hr' which is dedicated to TTS in the Balkans, the total financial transactions of thirty-nine TTS in 2011 and 2012 was 279.5 million Euros (Jasmina as cited in Panjeta, 2014: 142).

${ }^{3}$ For detalied information; Karlidag \& Bulut, 2014: 86 and Kuyucu, 2019: 572. 
The fact is, TTS reach millions in various countries of the world. It means that Turkish culture, Turkish art, Turkish music, and also Turkish brands reach millions in various countries of the world. According to the Turkish Grand National Assembly, stated Minister Mehmet Nuri Ersoy; up to the $30 \%$ of the expenses made in Turkey of foreign films and local productions that provide benefits to Turkey's promotion, that has been shown abroad, and that get rating are covered by the state (Saglam as cited in brandingturkiye, Mar 7, 2019).

Mehmet Nuri Ersoy, the Ministry of Culture and Tourism also mentioned that “...Turkey has reached to a huge number of exported Turkish TV series. It was ranked second after America with a $\$ 350$ million budget of exported TV series. We want to increase that appropriately and introduce Turkey correctly wherever Turkey is displayed." (EnsonHaber, Mar 5, 2019).

Demand for Turkish TV series also increased prices per episode. The prices of TTS in the world market have increased about ten times recently. TTS exporters aim to sign an export worth seven hundred fifty million dollars in 2023. Although the Middle East ${ }^{1}$, the Balkans and Eastern Europe, North Africa, South America, and Central Asia are the strongest markets for series exports. Recently, TTS are being watched almost everywhere in the world today. With the increase in production quality, the wages of the series sold abroad increased (Hurriyet, Apr 4, 2017).

As of 2019, it is seen that Turkish TV series have been broadcasted almost simultaneously in many different countries and there are many different series, and it is seen that these TV series have a large audience and fans. TTS which have started to be shown in countries such as Croatia, Bosnia-Herzegovina, Serbia ${ }^{2}$, Macedonia, Montenegro, and Kosovo in the Balkans in recent years, has succeeded in bringing together nations ${ }^{3}$ with different perceptions who cannot agree with each other on many issues (Aslan, 2019: 34).

As Cayli Rahte stated that geo-linguistic elements are also determinant for audiences in Balkan countries. Nearly five hundred years of Ottoman history in the former Yugoslavia provides a partnership whose traces are still visible in the cultural field, especially in the language (Cayli Rahte, 2017: 72).

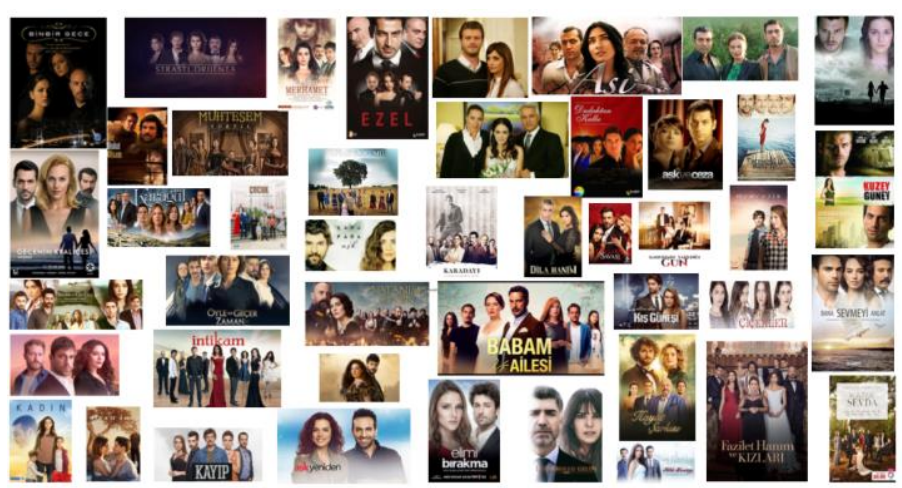

Figure 1. Turkish TV series shown in Croatia between 2010-2020

In the list below, which was created with the information obtained, there is a list of TTS, starting from the first TTS shown in Croatia in 2010, to date. This table also includes Turkish production company names and production years, Croatian names of productions, release year

\footnotetext{
${ }^{1} \mathrm{MBC}$ reports that in 2010, the audience reached three to four million viewers a day just in Saudi Arabia. According to Mazen Hayek, MBC Marketing, Public Relations and Commercial Affairs Director, " 85 million viewers in the Middle East and North Africa region (for the Noor -Gümüş- series final) are over 15 years old, 50 million of them are women.” (Aljammazi \& Asil, 2017: 212).

${ }^{2}$ According to Demirtas, the Turkish business volume is growing in Serbia and the Serbs want to come to Turkey to find work too. The second important point is the increasing interest in TTS in the region. Many people try to learn Turkish because they want to speak the language spoken by their favorite characters from the series. As Demirtas mentioned that Turkey and Serbs used to staring at the cold before but this situation is changing now. Many people from Serbia come to Turkey to spend some time. Turkey is the third place for Serbs after Greece and Montenegro to spend their holidays (Demirtas as cited in Yavuz \& Duygulu Elcim, 2019: 5).

${ }^{3}$ Wilson argues that the success of Turkish TV series in Chile stems from common social values. Vicente is also referring to the Turkish series as "They look like us, this is very close and very familiar things...". In Latin America, we are mainly Catholic and Turkey is mostly Muslim but we relate in same way how we confront social things" (Wilson and Vicente as cited in Pothou, 2018: 22).
} 
in Croatia, and Croatian channel names.

In Croatia, where the first TTS was shown with the "1001 Nights" series (Binbir Gece), it is seen that forty-five television series have been featured on private television channels (only one series in state channel) in the last ten years with increasing demand.

Table 1.

List of released Turkish TV series (TTS) in Croatia

\begin{tabular}{|c|c|c|c|c|c|c|}
\hline & TV Series & Production Company & $\begin{array}{l}\text { Production Year } \\
\text { in Turkey }\end{array}$ & Croatian Name & $\begin{array}{c}\text { Release Year } \\
\text { in Croatia }\end{array}$ & Channel \\
\hline 1 & Binbir Gece & TMC Film & 2006 & 1001. noć & 2010 & RTL \\
\hline 2 & Aşk-1 Memnu & Ay Yapım & 2008 & Strasti Orijenta & 2010 & $\begin{array}{l}\text { DOMA TV, } \\
\text { NOVA TV }\end{array}$ \\
\hline 3 & Ezel & Ay Yapım & 2009 & Ezel & 2010 & RTL \\
\hline 4 & Gümüş & D Productions & 2005 & Gumuš & 2010 & NOVA TV \\
\hline 5 & Asi & Sis Yapım & 2007 & Asi & 2010 & NOVA TV \\
\hline 6 & Menekşe ile Halil & Ay Yapım & 2007 & Bijeg & 2011 & NOVA TV \\
\hline 7 & Dudaktan Kalbe & Ay Yapım & 2007 & Kismet & 2011 & RTL \\
\hline 8 & Annem & Gold Film & 2007 & Moja majka & 2011 & DOMA TV \\
\hline 9 & Kaybolan Yillar & Base yapım & 2006 & Sjene prošlosti & 2011 & DOMA TV \\
\hline 10 & Yaprak Dökümü & Ay Yapım & 2005 & Kad lišće pada & 2011 & NOVA TV \\
\hline 11 & Aşk ve Ceza & TMC Film & 2010 & Ljubav i kazna & 2011 & NOVA TV \\
\hline 12 & Muhteșem Yüzyıl ${ }^{1}$ & Tims Production & 2011 & $\begin{array}{l}\text { Sulejman } \\
\text { Veličanstveni }\end{array}$ & 2012 & RTL \\
\hline 13 & $\begin{array}{l}\text { Öyle Bir Geçer } \\
\text { Zaman Ki }\end{array}$ & D Productions & 2010 & $\begin{array}{l}\text { Kako vrijeme } \\
\text { prolazi }\end{array}$ & 2012 & NOVA TV \\
\hline 14 & Fatmagül'ün Suçu Ne & Ay Yapım & 2010 & Izgubljena čast & 2012 & NOVA TV \\
\hline 15 & Dila Hanım & $\begin{array}{l}\text { Gold Film } \\
\text { (Production) }\end{array}$ & 2012 & Dila & 2013 & NOVA TV \\
\hline 16 & Kuzey Güney & Ay Yapım & 2011 & Nebo i zemlja & 2013 & NOVA TV \\
\hline 17 & Bir Bulut Olsam & Tims Production & 2009 & Da sam oblak & 2013 & NOVA TV \\
\hline 18 & İntikam & D Productions & 2013 & Osveta & 2013 & RTL \\
\hline 19 & Merhamet & Most Production & 2013 & Milost & 2013 & NOVA TV \\
\hline 20 & Benim İçin Üzülme & Boyut Film & 2012 & $\begin{array}{l}\text { Ne brini za } \\
\text { mene }\end{array}$ & 2013 & RTL \\
\hline 21 & Karagül & Avşar Film & 2013 & Crna ruža & 2014 & NOVA TV \\
\hline 22 & Karadayı & Ay Yapım & 2012 & Časni ljudi & 2014 & NOVA TV \\
\hline 23 & Kara Para Aşk & Ay Yapım & 2014 & Ljubav i novac & 2015 & NOVA TV \\
\hline 24 & $\begin{array}{l}\text { Kaderimin Yazıldığı } \\
\text { Gün }\end{array}$ & O3 Production & 2014 & Sudbina & 2016 & NOVA TV \\
\hline 25 & Medcezir & Ay Yapım & 2013 & Plima i oseka & 2016 & DOMA TV \\
\hline 26 & Fatih Harbiye & Koliba Film & 2013 & Pitanje časti & 2016 & NOVA TV \\
\hline 27 & Vatanım Sensin & O3 Production & 2016 & Ranjena ljubav & 2016 & RTL \\
\hline 28 & Kış Güneşi & $\begin{array}{l}\text { Endemol Shine } \\
\text { Turkey }\end{array}$ & 2016 & $\begin{array}{l}\text { Ponovno } \\
\text { rođen }\end{array}$ & 2016 & NOVA TV \\
\hline 29 & Kırgın Çiçekler & NTC Medya & 2015 & Anđeli & 2016 & NOVA TV \\
\hline 30 & Gecenin Kraliçesi & O3 Production & 2016 & Kraljica noći & 2016 & HRT1 (State Ch.) \\
\hline
\end{tabular}

\footnotetext{
1 "The Sulejman Magnificent series, whose episodes of Monday through Thursday and Sunday in one breath averages over 750,000 viewers across Croatia, will have a break in airing over the Christmas and New Year holidays between December 21 and January 13, 2013. The series returns to the screens with a double episode on Sunday, January (2012) 13 at 8 pm" (rtl.hr). As can be understood from this information, it is seen that the screening of this series is especially suspended during Christmas and New Year's Eve. This is thought to be due to religious sensitivities.
} 


\begin{tabular}{|c|c|c|c|c|c|c|}
\hline & TV Series & Production Company & $\begin{array}{c}\text { Production Year } \\
\text { in Turkey }\end{array}$ & Croatian Name & $\begin{array}{c}\text { Release Year } \\
\text { in Croatia }\end{array}$ & Channel \\
\hline 31 & Babam ve Ailesi & $\begin{array}{l}\text { Gold Film } \\
\text { (Production) }\end{array}$ & 2016 & $\begin{array}{l}\text { Obitelj mog } \\
\text { oca }\end{array}$ & 2017 & NOVA TV \\
\hline 32 & Bana Sevmeyi Anlat & Ay Yapım & 2016 & $\begin{array}{l}\text { Nauči me } \\
\text { voljeti }\end{array}$ & 2017 & NOVA TV \\
\hline 33 & Kara Sevda & Ay Yapım & 2015 & Bit ćeš moja & 2017 & NOVA TV \\
\hline 34 & Kayıp & D Productions & 2013 & Ukradeni život & 2018 & NOVA TV \\
\hline 35 & Aşk Yeniden & Süreç Film & 2015 & Začin ljubavi & 2018 & NOVA TV \\
\hline 36 & Kördüğüm & $\begin{array}{c}\text { Endemol Shine } \\
\text { Turkey }\end{array}$ & 2016 & Kazna & 2018 & NOVA TV \\
\hline 37 & Hayat Şarkısı & Most Production & 2016 & $\begin{array}{l}\text { Djevojka sa } \\
\text { sela }\end{array}$ & 2018 & NOVA TV \\
\hline 38 & Güllerin Savaşı & Med Yapım & 2016 & Rat ruža & 2018 & NOVA TV \\
\hline 39 & Istanbullu Gelin & O3 Production & 2017 & $\begin{array}{l}\text { Istanbulska } \\
\text { nevjesta }\end{array}$ & 2018 & NOVA TV \\
\hline 40 & Kadın & Med Yapım & 2017 & Žena & 2018 & RTL \\
\hline 41 & $\begin{array}{l}\text { Fazilet Hanım ve } \\
\text { Kızlar1 }^{1}\end{array}$ & Avşar Film & 2017 & $\begin{array}{l}\text { Fazilet } \mathrm{i} \\
\text { njezine kćeri }\end{array}$ & 2019 & NOVA TV \\
\hline 42 & Siyah İnci & Gold Film & 2017 & Crni biser & 2019 & NOVA TV \\
\hline 43 & Hercai & Mia Yapım & 2019 & $\begin{array}{l}\text { Ljubav } \\
\text { osvetnika }\end{array}$ & 2019 & NOVA TV \\
\hline 44 & Elimi Bırakma & Üs Yapım & 2018 & Azra & 2019 & NOVA TV \\
\hline 45 & Çocuk & 1441 Production & 2019 & Dijete & 2020 & NOVA TV \\
\hline
\end{tabular}

Commercial televisions (Nova TV and RTL TV) arrived in Croatia after they started broadcasting in the 2000s. With the advent of neo-television, there has been a significant decrease in the broadcast share of programs offered in the fields of arts, culture, science and education, while a tremendous increase in fiction programs (Peruško \& Čuvalo, 2014: 149).

Nova TV was the first Croatian commercial television network, launched in November 2000. Nova TV introduced Croatian audiences to American reality series and other contemporary formats and started the trend of different talent shows in Croatia. Its most popular program is the central news show called 'Dnevnik Nove TV', which is followed by a drama program, either Croatian or foreign. Doma TV is a part of Nova TV's grupation which focuses only on series, mostly foreign.

RTL Televizija is another commercial network that was first launched in April 2004 and is 99.9\% owned by the RTL Group. It is quite similar to Nova TV in terms of the content it shows, but due to its belonging to the RTL Group, it shows more content originating from Germany. RTL television first introduced TTS to Croatian audiences.

Croatian Radiotelevision (Hrvatska radiotelevizija [HRT]) is the Croatian public ${ }^{2}$ broadcasting company. It has only aired one TTS, 'Queen of the Night'. As a public network, it has faced some pressure not to air Turkish TV content due to misplaced beliefs by some viewers that it is low quality and unworthy of being aired on Croatia's public network, although HRT has shown numerous Mexican telenovelas and other series of questionable quality.

With regards to the selection of TTS to be shown in Croatia (As of October 2019), it seems to depend on each TV station's original production and potential for marketing profit. A current example would be NOVA TV's decision to move the hugely popular 'Mrs. Fazilet and her Daughters' (Fazilet Hanım ve Kızları) into a later air time after introducing its own TV show

\footnotetext{
${ }^{1}$ Due to the fact that Turkish names are not Slavic and therefore not entirely compatible with the Croatian phonetic system, there are certain instances in which Croats have adapted them into more familiar-sounding words, either due to not being able to pronounce them correctly or to be humorous. For example, the character Fazilet from the series "Mrs. Fazilet and her daughters" is often jokingly called 'Fažolet (a dialectal Croatian word for green beans), and the actor Burak Ozcivit is sometimes referred to as 'Burek' (baked filled pastries, a dish eaten in both Croatia and Turkey -Börek-).

${ }^{2}$ For detailed information about public broadcasting; Okumus, 2020: 54-55.
} 
'Drugo ime ljubavi' (Croatian TV series) and airing it at 20:00. After the end of 'Mrs. Fazilet and her Daughters', NOVA TV purchased another TTS, 'Black Pearl', which was not very popular with the audiences nor critics in Turkey. This show is currently airing at 18:00, likely to just fill empty air time, not to become a bestseller such as the extremely popular '1001 Nights' (Binbir Gece), 'Forbidden Love' (Aşk-1 Memnu), or 'Asi' (Asi) which all aired at or around 20:00 in times when the channels that showed them did not have any original productions to air.

\section{A Case Study}

\subsection{Focused Research \& Methodology}

In this research, as mentioned before the main aim to understand and analyze television viewers' awareness of TTS as well as understanding and analyzing the TV series habits in Croatia. In order to achieve this, a specially prepared questionnaire study was planned to bring the attention of the participants. In this regard, it was planned in order to measure the social status of the participants, their habits of watching TV series in cultural terms, and their original attachment to Turkish television series, regardless of their socio-cultural status, age or gender.

\subsection{Access to Participants}

The fact that the participants were selected from the designated forum site (www.forum.hr) is due to researchers' desire to rely on the knowledge and experience of a loyal audience who is knowledgeable about the subject. It is important for this study to get the answers of an influential audience that has a serious experience on television series with the effect of the interactive interviews that the participants have made about the TV series watched or watching, as well as having knowledge on both Turkish and foreign TV series. Because one of the most important criteria is that the participants; it is the fact that they must have an effective and competent knowledge of the subject of this research.

\subsection{Data Collection}

This research, which is based on TTS broadcasted in Croatia, is planned to reach a conclusion through the online questionnaire created to understand the preferences of the Croatian viewers and how these preferences are shaped. In this sense, this questionnaire, consisting of twentythree questions, was available with no time restrictions. The reason for not having any time restrictions is to make a healthier and more realistic situation analysis in terms of the results of the study by reaching the highest participation number. However the results were collected between September 13-20, 2020 from 'www.forum.hr' site. The questionnaire was presented to the attention of the audience who followed or follows the series at the website under the title of "television" (televizija) and under the sub-title "the soap operas" and "non-shown soap operas" (sapunice i neprikazano - sapunice). With the thought that there may be participation/participants from other Balkan countries (Croatia (Hrvatska), Serbia (Srbija), Bosnia and Herzegovina (Bosna $i$ Hercegovina), Slovenia (Slovenija), Macedonia (Makedonija), Montenegro (Crna Gora), Kosovo and other) who follow this forum, the first question asked in the survey was 'the country you live in' and all answers was filtered according to countries of the participants and only the answers are given by the Croatian audiences ${ }^{1}$ about TTS were taken into account.

\subsection{Research Ethics}

As Potter (1996) states, researchers should reflect on the collected data as it is without distorting

\footnotetext{
${ }^{1}$ When the answers from other countries were extracted from the responses of the seventy participants in the survey, only the remaining forty Croatian audiences' responses were analyzed.
} 
or ignoring it (Saka \& Göncü, 2017: 7). In addition to the sensitivity shown to this issue, ensuring the confidentiality of the collected data and participant information has also great importance within the ethical framework. For this reason, the information that the identities and information of all participants who contributed to this study will be kept confidential as it was declared at the beginning of the survey, ${ }^{1}$ and in this way, confidentiality is being respected. Additionally, all participants were sent the same questionnaire form.

\section{Findings}

In total, it was observed that seventy people (forty from Croatia, eleven from Serbia, fourteen from Bosnia and Herzegovina, three from Slovenia, one from Serbia, and one from Montenegro) participated in the survey. In terms of our study, as stated before, the study aims to reach a conclusion only based on the responses of the Croatian audience. In this sense, the answers are filtered and only the answers of the Croatian audience are conveyed as the findings given by forty Croatian.

Thirty-two of the forty participants in total are women, seven are men, and the remaining one is a person who does not want to specify its gender participated in our survey.

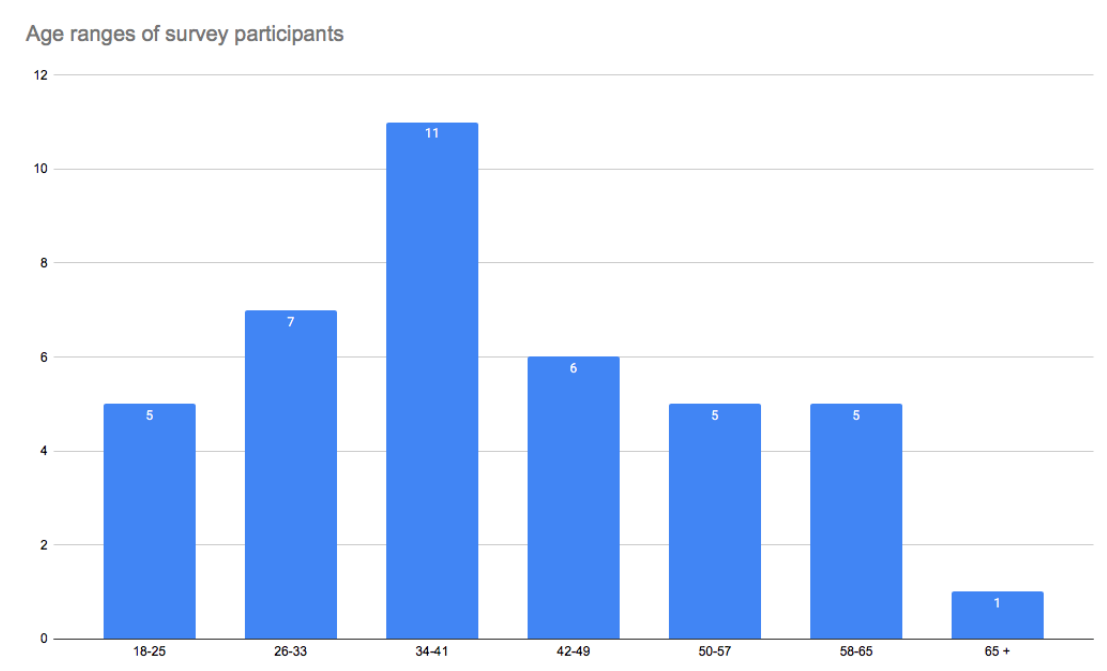

Figure 2. Age ranges of survey participants

Five of the respondents from Croatia included the age range 18-25, seven aged 26-33, eleven aged 34-41, six aged 42-49, five aged 50-57, five aged 58-65, and the last one stated 65+ as above (Figure 2).

Nineteen of the participants stated that they were university graduates, three of them graduated from master's and doctoral degrees, one of them was high school graduates, and seventeen of them were middle school graduates.

Eleven of the participants stated that they have an income less than 3250 kuna, five people in the range of 3250 kuna-5000 kuna, fourteen people in the range of 5000 kuna-7000 kuna, seven people in the range of 7000 kuna-10000 kuna, and the remaining three people in the range of more than 10000 kuna.

\footnotetext{
${ }^{1}$ Poštovani, Hvala Vam na sudjelovanju u ovoj anketi! Cilj ove ankete je utvrditi i procijeniti informacije o navikama i trendovima gledanja televizije u Hrvatskoj, a rezultati će se koristiti u pisanju akademskog članka. Anketa je anonimna, a svi podaci povjerljivi te će se analizirati kolektivno u svrhu predmetnog istraživanja. Molimo odgovorite na anketu samo jednom. Da bi statistička analiza bila valjana, molimo vas da nijedno pitanje ne ostane prazno. Hvala vam.

Dear Participant, This questionnaire was prepared within the scope of an academic article. The survey aims to determine and evaluate information about television viewing habits and trends in Croatia. The survey is anonymous and all information is kept confidential. The results will be assessed collectively to serve only the research in question. Please complete your answers only once. In order to make the statistical analysis valid, we kindly ask that no questions should be left empty. Thank you.
} 
Thirty people from the participants stated that they live together with their family, seven of them live alone, and the remaining three people selected 'other' choice.

According to marital status answers, eighteen of the participants are single, fifteen of them are married, one is divorced, one of them is a widow, three of them stated that they have a relationship, and the remaining two people chose not to report their situation.

Nineteen of the participants stated that they are working in the private sector, seven of them are working in the state, four of them are retired, five of them are students, and the remaining five people are unemployed.

Twenty-eight people from the participants declared the rate of watching television 'daily during the week' is 0-2 hours, eleven people stated that it is 2-5 hours, and the remaining person stated that it is $10-15$ hours.

Twenty-three of the participants stated the average 'television watching rate on a weekend' as between $0-2$ hours, fourteen people stated between 2-5 hours, and the remaining three people stated between 5-10 hours.

When the participants are asked what kind of TV series they watch, the results obtained from the forty participants are clearly seen in the Figure 3. As stated in the chart drama (16,8\% means thirty people), romance $(16,2 \%$ means twenty-nine people), and documentary $(10,1 \%$ means eighteen people) are included in the top three.

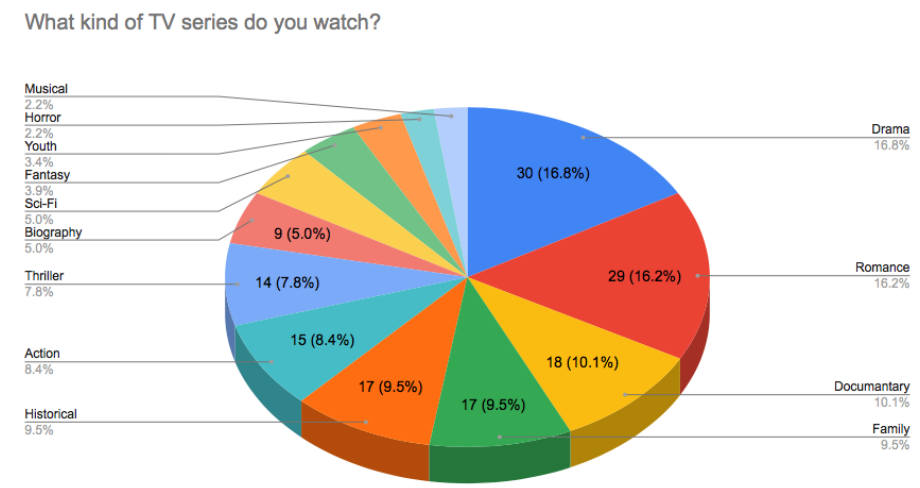

Figure 3. What kind of tv series do you watch?

The answers received from the participants when asked 'what motivates you to continue watching the TV series' are like in the Figure 4. According to this chart, in Croatia, it is seen that the three main elements that determine the habits of watching TV series, in general, are the story $(22,1 \%$ means thirty-six people), female and male actors (16\% means twenty-six people) and content (14,7\% means twenty-four people).

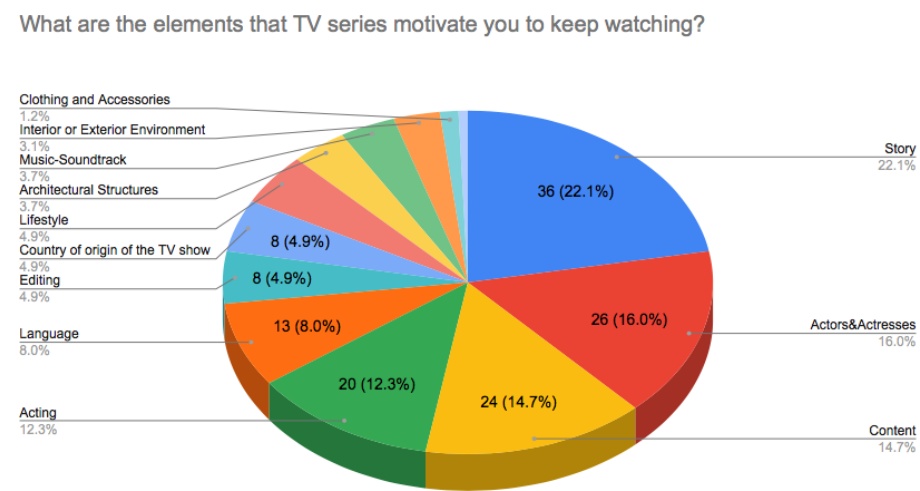

Figure 4. What are the elements that tv series motivate you to keep watching?

According to another piece of information obtained from the survey results, thirty-seven participants stated that they watched/watching TTS, while three of them stated that they did 
not. The participants who stated that they did not watch TTS, two of them were between the ages of 34-41 (single male), and the other as over 65+ (retired married woman). In addition, these people declared that they watch only American, Latin American, and European TV series. Eleven of the participants stated that they watched TTS only on television, nineteen from the internet, nine from both, and one person answered this question with the 'other' option.

Nine participants stated that they watched 1-5 TTS in the last ten years, six people between 510, six people between 10-15, five people between 15-20, and fourteen people (35\%) stated that they watched 20 or more TTS.

When the participants are asked which series they have watched among the TTS (previously presented in table 1 above) broadcast on Croatian television channels in the last ten years, all answers shown in the Figure 5. According to this, it is seen that the most-watched series is "1001. noć (Binbir Gece, 2006)", the second one is "Ljubav i novac (Kara Para Aşk, 2014)", the third one is "Fazilet i njezine kćeri (Fazilet Hanım ve Kızları, 2017)", the fourth one is "Strasti Orijenta (Aşk-1 Memnu, 2008)", and the fifth one is "Izgubljena čast (Fatmagül'ün Suçu Ne?, 2010)" The series left at the end of the list with the least number of views is "Sjene prošlosti (Kaybolan Y1llar, 2006)". According to the data, it has been observed that the series published as "Kismet" (Dudaktan Kalbe, 2007) was never watched among the respondents.

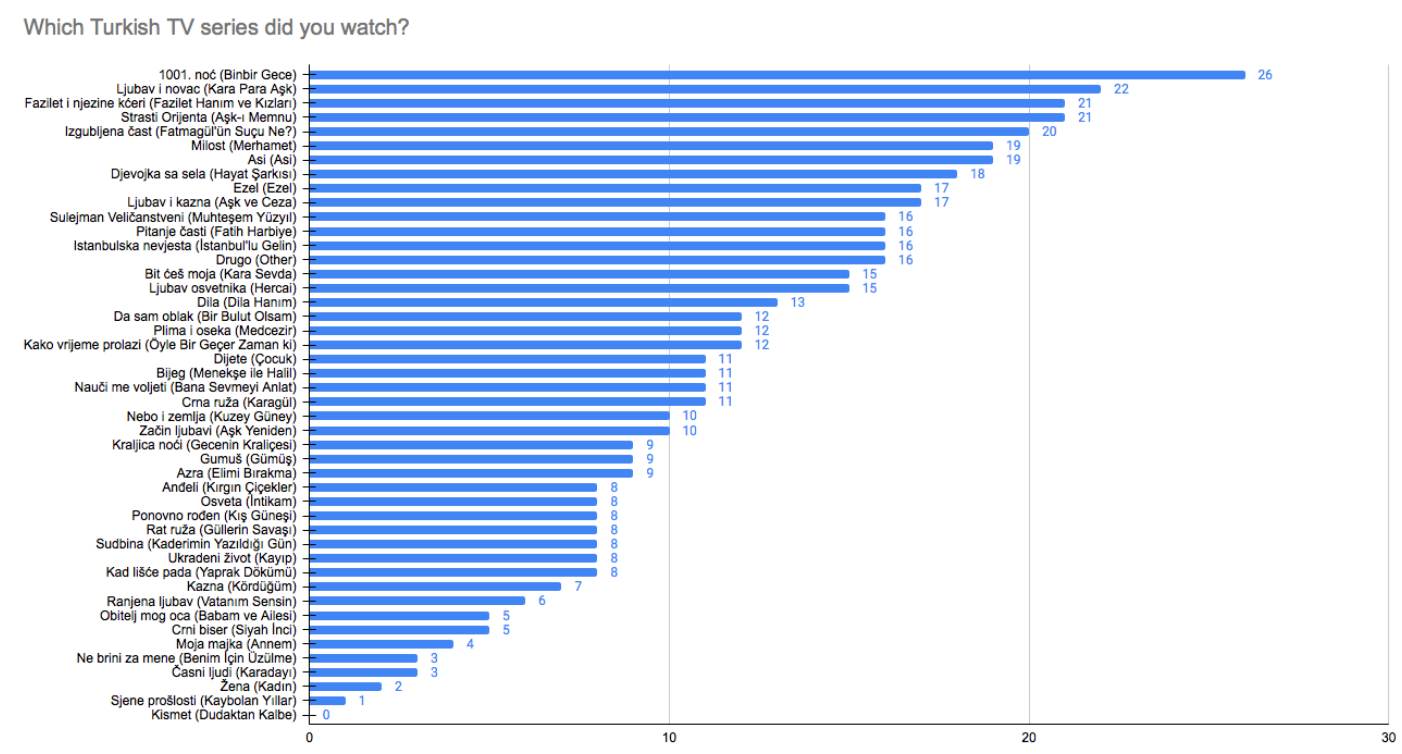

Figure 5. Which Turkish tv series did you watch?

Seventeen participants $(42,5 \%)$ expressed their opinion about the quality of TTS as "very good", thirteen people $(32,5 \%)$ as "good", nine people $(22,5 \%)$ expressed their opinion as "neither good nor bad", and the remaining one as "bad".

When asked what motivates the participants in watching/following TTS; it is obviously seen in the chart below (Figure 6) that the most important factor is the story/scenario, then the selection and harmony of the male and female actors, and then the acting. The most insignificant part was stated to be the dress and accessories preferences in the series projects. 
What are the elements that Turkish TV series (TTS) motivate you to keep watching?

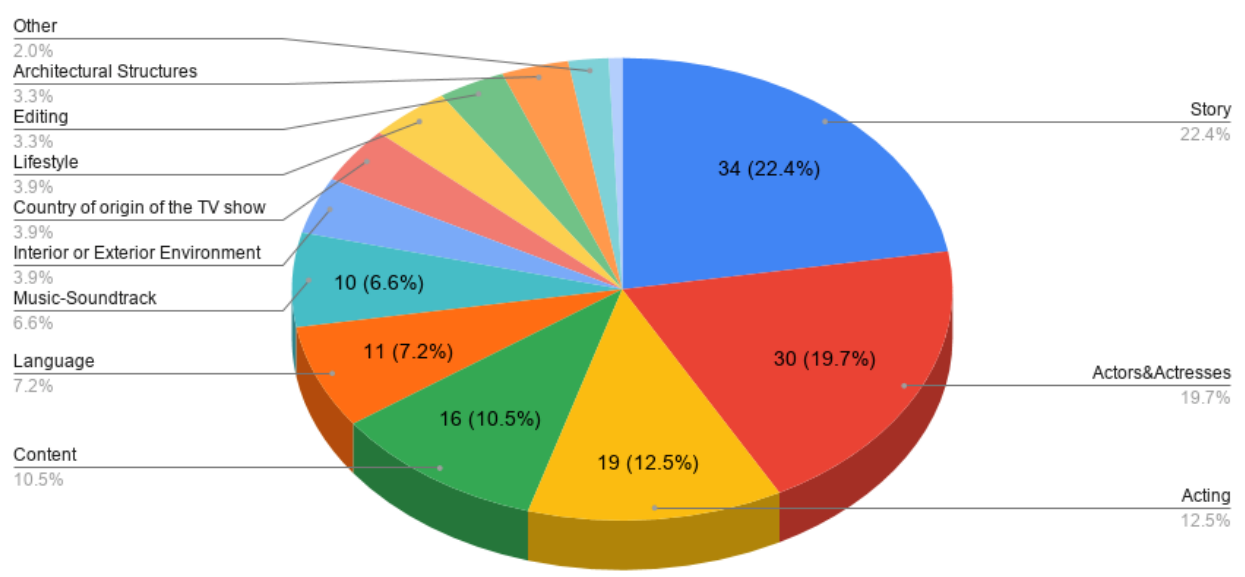

Figure 6. What are the elements that Turkish tv series (TTS) motivate you to keep watching?

Considering the information obtained from graph 3 , it is seen that although there is a great similarity in the viewpoints of Croatians on TTS and other series, there are small differences in terms of detail. In this sense, it is seen that Croats primarily look at the story, male and female actors, and content in TV series, when it comes to TTS, Croats look at the story, female and male actors, and acting in the first three rankings.

Thirty-six people out of the forty participants stated that they generally give importance to the story in the TV series, and thirty-four people stated that the story is the first option when it comes to TTS.

Twenty-six of the forty participants stated that they attach importance to the harmony of male and female actors in the TV series, and when it comes to TTS, thirty people give importance to the harmony of male and female actors.

Twenty-four participants out of the forty participants generally think that the contents of the series are important, but when it comes to TTS, nineteen people stated that acting is the third. When the participants were asked "are there any other TTS that you watch over the internet, other than released on TV?" twenty-four of them answered as yes, and sixteen of them answered as no. According to the 'yes' answers, it is seen that $60 \%$ of the participants watch TTS on the internet.

When asked "how many Turkish TV series you follow on the internet, other than released on TV?" to the participants, twenty respondents answered 1-3, two answered 4-6, four respondents selected 10 and above, and fourteen had none.

According to the answers given to the question "what other TV series are you watching on the internet other than released on television?" it was seen that the participants selected thirtyseven TV series (the first and oldest one which was published in 2004 and to the current series that just started or will start today as of September 2020).

Table 2.

TTS names that Croatian audiences follow on the internet, excluding tv

\begin{tabular}{lll}
\hline Year & \multicolumn{1}{c}{ Turkish Series Name } & \multicolumn{1}{c}{ Croatian Series Name } \\
\hline 2004 & Aliye & Alije \\
2005 & Hırsız Polis & Lopovska policija \\
2006 & Hatırla Sevgili & Zapamti draga \\
2006 & Firtına & Oluja \\
2007 & Bıçak Sirtı & Oštrica noža \\
2013 & Güneşi Beklerken & Čekajući sunce \\
\hline
\end{tabular}




\begin{tabular}{|c|c|c|}
\hline Year & Turkish Series Name & Croatian Series Name \\
\hline 2014 & Zeytin Tepesi & Maslinovo brdo \\
\hline 2014 & Diriliş Ertuğrul & Uskrsnuće Ertugrul \\
\hline 2015 & Poyraz Karayel & Poyraz Karayel \\
\hline 2016 & Bodrum Masalı & Priča iz Bodruma \\
\hline 2017 & Çukur & Jama \\
\hline 2017 & Masum & Nevina \\
\hline 2017 & Siyah Beyaz Aşk & Crno-bijela ljubav \\
\hline 2018 & Gülperi & Gulperi \\
\hline 2018 & Şahsiyet & Osobnost \\
\hline 2018 & Yasak Elma & Zabranjena jabuka \\
\hline 2018 & Erkenci Kuş & Ranoranioc \\
\hline 2019 & Afili Aşk & privržena ljubav \\
\hline 2019 & Tek Yürek & Jedno srce \\
\hline 2019 & Sefirin K1z1 & Ambasadorova kcer \\
\hline 2019 & Doğduğun Ev Kaderindir & Dom u kojem si rodjen je tvoja sudbina \\
\hline 2019 & Mucize Doktor & Čudotvorni liječnik \\
\hline 2019 & Atiye & Dar \\
\hline 2019 & Hercai & Ljubav osvetnika \\
\hline 2019 & Her Yerde Sen & Posvuda ste \\
\hline 2020 & Sen Çal Kapımı & Pokucaj na moja vrata \\
\hline 2020 & İyi Günde Kötü Günde & U dobrim danima u lošim danima \\
\hline 2020 & Alef & Aleph \\
\hline 2020 & Bay Yanlış & Gospodin Pogresni \\
\hline 2020 & Menajerimi Ara & Pozovite mog menadzera \\
\hline 2020 & Aşk 101 & Ljubav 101 \\
\hline 2020 & Kirmızı Oda & Crvena Soba \\
\hline 2020 & Babil & Babilon \\
\hline 2020 & Yeni Hayat & Novi zivot \\
\hline 2020 & Maria ile Mustafa & Marija i Mustafa \\
\hline 2020 & Ramo & Ramo \\
\hline 2020 & Arıza & Kvar \\
\hline
\end{tabular}

As seen in the chart below (Figure 7), most of the participants (30.4\%) stated that they watched TTS in the first line, then American TV series, and then European TV series. Afterward, it is seen that Latin American and domestic TV series take the last place.

\section{Which region's TV series do you prefer to watch?}

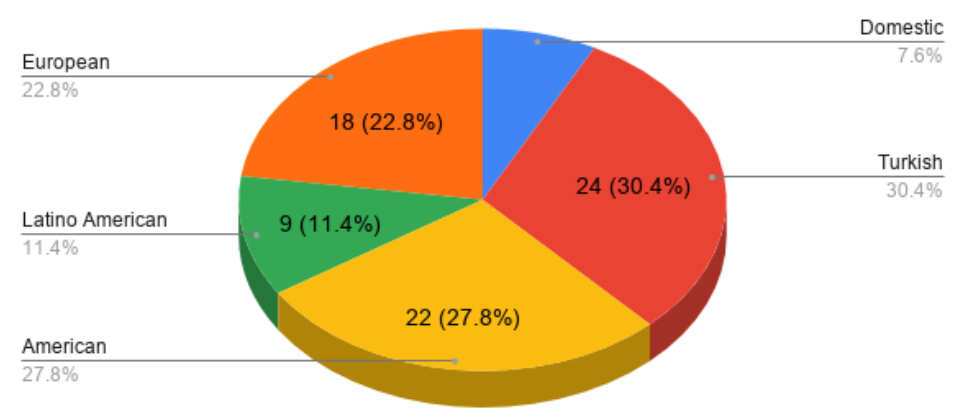

Figure 7. Which region's tv series do you prefer to watch?

Only one female participant (age between 58-65) ${ }^{1}$ made additions to the survey's question ("is there anything you want to add?") -which were important- it was placed as the last question in

\footnotetext{
${ }^{1}$ Another female person from Bosnia and Herzegovina (between 42-49) stated that "I don't know for what reason it doesn't matter to the Turks, but for fans of the series from any part of the world, it is important that the story has a reasonable flow of time and that attention should be paid to that. In the Turkish series, it often happens that someone in the 5 th episode is 20 years married, and in the 10th episode we watch
} 
the survey and was asked due to the participants' desire to reach some key points based on their own experiences. Croatian female audience expresses her opinion as follows,

\footnotetext{
It would be great to shorten the duration of individual episodes... too long, sometimes unnecessarily protracted, precisely, to achieve minutes, and it especially bothers me that they change the story during filming... that rating determines the rules and what under by pressing the same rating, sometimes they end the series in vain and incoherently... it's a pity because they have great actresses, quality screenwriters, beautiful exteriors and a culture of life that we are not used to in this area, so stories from so-called rural areas with an emphasis on the tradition of very attractive...
}

she mentions as a summary that extending sections unnecessarily overshadow the success of the episodes in other parts.

\section{Conclusion}

The main purpose of this study was to understand and present the demands of the Croatian audience for TTS and the reasons for their consumption. In this sense, the study searches for any close relationship between Turkey and Croatia in terms of sociological, cultural, and also traditional ties. It has been observed from the research that the cultural and traditional ties that we presented as a hypothesis at the beginning of the study and which appeared in other countries' studies were not effective in the context of TTS in Croatia.

The second aim of this study was to investigate the perspectives, consumption preferences and effects of TTS broadcasted in Croatia in the last ten years. The findings obtained from the study make many contributions to the existing literature. First of all, it provides important information to researchers on behalf of the Croatians' perspective on TTS. Second, consistent answers have been reached by the Croats in terms of the reasons for watching TTS and their consumption.

This study has shown that Croatian audiences evaluated the projects from a purely professional point of view, and at first glance, they evaluated the story, then the harmony of male and female actors, and thirdly acting. It has also been observed that the most preferred TV series between domestic, American, Latin American, and European TV series broadcasted in Croatia are TTS ones. Moreover, TTS which are mostly preferred by female viewers, have been observed to consume more TTS regardless of economic and educational level, and even educated people. There is no information that can be associated with age, gender, income, and educational status of the participants to watch TV series or TTS. Participants were observed to follow TTS in different age ranges, with different income and education levels, regardless of whether they are private-sector employees (except two out of seven), government employees or retired (except one out of four).

The findings of this study briefly show that Croatia like every other country in the world has a different perspective and expectation towards TTS. In this sense, this study will take its place in the bigger picture and will be beneficial for future studies about TTS.

\section{Acknowledgments}

This research would not have been possible without the generous support of Maja Bradić. I would like to thank her once again for her valuable contributions and unique information on

\footnotetext{
the celebration of the 20th anniversary of the marriage. Or they met and fell in love in their youth, twenty years ago, and she is now 25 he 35 . So a 15 -year-old boy fell in love with a 5-year-old girl (horror). When the series passes into the second season they fall out of the sleeves of various aunts or grandmothers, never mentioned before in the series. Spinning in a circle also bores people, so they decide to watch it online, where they can skip most of the episode. The lack of a normal kiss and their touch, which doesn't have to be particularly intimate after the initial euphoria for the Turkish series, also gets on my nerves. No, on no grounds is it normal for a husband and wife to neither kiss nor touch, let alone a young couple in love. It does not have to be exaggerated, but if violence does not corrupt the youth, love will certainly not corrupt them. The number of weapons that are taken out every now and then, the shooting to which no one reacts, neither the police nor the neighborhood give the impression that life in Turkey is as it used to be in the Wild West." As it can be clearly understood from the state of the participant that the temporal jumps made in terms of "timeline" on the scenario cause serious difficulties in terms of understanding the story.
} 
the subject. On the other hand, I would like to thank Yalcin Armagan for his interest, encouragement, and also his feedbacks who made valuable contributions to this study, which I shared as an idea at the beginning of the study. Finally, I would like to express my gratitude to Bengisu Filiz Karakurt for her reading and corrections.

\section{References}

Abisheva, A. (2019). The Effect of Turkish Television Series and Films on the Country's Image and Travel Tendency: The Case of Kazakhstan. MA Thesis. Ankara Haci Bayram Veli University.

Agirseven, N. \& Orki, A. (2017). Evaluating Turkish TV Series as Soft Power Instruments. International Journal of Society Researches.

Aljammazi, A. \& Asil, H. (2017). The Influence of Turkish TV Dramas on Saudi Consumers' Perceptions, Attitudes and Purchase Intentions toward Turkish Products. International Journal of Academic Research in Business and Social Sciences, 2017, Vol. 7, No. 1, ISSN: 2222-6990.

Aslan, P. (2019). International Communication within the Context of Popular Culture: A Study on the Success Turkish Television Series Have Had in Latin America. Istanbul University Journal of Communication Sciences, 2019, 57, 25-50. doi: 10.26650/CONNECTIST20190052 .

Binbir Gece (2006), 1001 Noć (2010). https://www.famousfix.com/topic/binbir-gece/photos (Accessed: May 21, 2020).

Brandingturkiye / "Türkiye dizi ihracatında ikinci sırada". https://www.brandingturkiye.com/turkiye-dizi-film-ihracatinda-2-sirada/ (Accessed: Aug 30, 2019).

Cakir, F. (2013). The Effect of TV Series on Destination Image. Adnan Menderes University, Journal of Institute of Social Sciences, Vol.: 1, Issue: 2, p. 80-89.

Cayli Rahte, E. (2017). Global Flow of Culture and Media: The Audience Reception of Turkish TV Series in Kosovo.

EnsonHaber, "Türkiye dizi film ihracatında ikinci sırada". https://www.ensonhaber.com/turkiye-dizi-film-ihracatinda-2-sirada.html (Accessed: Aug 30, 2019).

Guardian, "Turkish TV Magnificent Century taking overworld". https://www.theguardian.com/tv-and-radio/2019/sep/13/turkish-tv-magnificent-centurydizi-taking-over-world (Accessed: Sep 14, 2019).

Gumus, N., Zhaxyglova, G., Mirzabekova, M. (2017). Using Turkish Soap Operas (TV Series) As a Marketing Communication Tool: A Research on Turkish Soap Operas in Kazakhstan. IJOESS, Vol.: 8, Issue: 27.

Hira, İ. \& Yildirim, E. (2016). Reflections of Orientalism on Turkish Television Series: The Magnificent Century Case. PESA International Journal of Social Studies, Vol.: 2, Issue: 2.

History of HRT, "The evolution of Croatian radio and television". https://www.hrt.hr/23183/povijest/the-evolution-of-croatian-radio-and-television. (Accessed: Nov 10, 2020).

Hurriyet, "Türk dizileri iki numara". http://www.hurriyet.com.tr/ekonomi/turk-dizileri-2numara-40417302 (Accessed: Aug 30, 2019). 
IMDB 'Mrs. Fazilet and her daughters' (2017). https://www.imdb.com/title/tt6756704/?ref_=nv_sr_srsg_0 (Accessed: Oct 21, 2020).

IMDB, 'Queen of the Night' (2016) Kraljica noći (2016). https://www.imdb.com/title/tt5303602/ (Accessed: Oct 21, 2020).

Jutarni - Seherezada has won! new-tv-its-soap-has-been-canceled-after-only-four-episodes. https://www.jutarnji.hr/spektakli/ups/seherezada-je-pobijedila-nova-tv-svoju-je-sapunicuukinula-nakon-samo-cetiri-epizode/2133381/ (Accessed: Aug 29, 2019).

KanalD - Binbir Gece. https://www.kanald.com.tr/binbirgece (Accessed: Aug 29, 2019).

Karlidag, S. \& Bulut, S. (2014). The Transnational Spread of Turkish Television Soap Operas. Istanbul University, Journal of Communication Faculty.

Kuyucu, M. (2019). Young People's Attitudes Towards The TV Series Produced in Turkey and Analysis of The Factors of Series Consumption. International Journal of Cultural and Social Studies (IntJCSS). Volume 5 (Issue 2).

Matar, A. (2017). Tourist Destination Marketing: The Influence of Turkish Drama on Arab Tourists. MA Thesis. Bahcesehir University.

Nova TV. https://novatv.dnevnik.hr/o-nama/ (Accessed: Nov 9, 2020).

Okumus, M. S. (2020) The Transformation of Historical TV Series in the Context of Modernization and Hegemony under the Governance of TRT General Managers. Ph.D. Thesis. Marmara University, Institute of Social Sciences.

Ozdemir, S. G. \& Aktas, G. (2016). The Influence of Turkish TV-Series on Destination Image and Travel Motivation: Case of Athens. Anatolia: Turizm Araştırmaları Dergisi, V. 27, S. 1, Spring, p. 111-124.

Panjeta, L. (2014). The Changing Soaps and Telenovela Genre: Turkish Series Impact. Epiphany Journal of Transdisciplinary Studies, Vol. 7, No. 1, p. 137-168.

Peruško, Z. \& Čuvalo, A. (2014). Comparing Socialist And Post-Socialist Television Culture: Fifty Years Of Television in Croatia. View Journal of European Television History and Culture (Netherlands) Vol. 3, p. 131-150.

Pothou, E. (2018). An Audience Research on Turkish TV Series Among Greek Audience. MA Thesis, Istanbul Bilgi University, Institute of Social Sciences.

RTL Televizija. https://www.bce.lu/rtl-televizija/ (Accessed: Nov 9, 2020). https://logos.fandom.com/wiki/RTL_(Croatia) (Accessed: Nov 9, 2020).

RTL - The Sulejman Magnificent. https://www.rtl.hr/vijesti-hr/scena/586985/vrhunac-drameu-sulejmanu-uoci-prekida-serije/ (Accessed: Sep 17, 2019).

Saka, E. \& Goncu, B. (2017). How Turkish Pr Professionals and Students Use Digital Resources. Intermedia International e-Journal, Spring -June - 2017 4(6). doi: 10.21645/intermedia.2017.24.

Sinematurk - Binbir Gece. http://sinematurk.com/film/17854-binbir-gece/ (Accessed: Aug 29, 2019).

Sputniknews - “İspanya ve Latin Amerika'da Türk dizilerine neden büyük ilgi gösteriliyor?”. https://tr.sputniknews.com/columnists/201909161040184081-ispanya-ve-latin-amerikadaturk-dizilerine-neden-buyuk-ilgi-

gosteriliyor/?utm_source=short_direct\&utm_medium=short_url\&utm_content=9KMX\&ut m_campaign=URL_shortening (Accessed: Sep 17, 2019). 
Variety - "MipTV: Turkish TV Series "The End' Scores First European Redo". https://variety.com/2016/tv/global/miptv-turkish-tv-series-the-end-scores-first-europeanredo-1201743633/ (Accessed: Sep 19, 2019).

Yavuz, T. \& Elcim, S. D. (2019). Turkey's Soft Power and Public Diplomacy: The Case of Serbia Between 2002-2019. Qualitative Social Sciences.

Youtube - Berguzar Korel and Halit Ergenc - Reklama za Konzum. https://www.youtube.com/watch?v=SFkoM9vqk7k (Accessed: Dec 5, 2020).

Yoruk, Z. \& Vatikiotis, P. (2013). Soft Power or Illusion of Hegemony: The Case of the Turkish Soap Opera "Colonialism" International Journal of Communication 7 (2013), p. 2361-2385, 1932 - 8036/20130005. 


\section{Appendix}

\section{Research Questions}

The following questions were asked to the participants in the questionnaire which was prepared on the Google Survey.

1- U kojoj zemlji živite? (Which country do you live in?) *

- Hrvatska (Croatia)

- Srbija (Serbia)

- Bosna i Hercegovina (Bosnia and Herzegovina)

- Slovenija (Slovenia)

- Makedonija (Macedonia)

- Crna Gora (Montenegro)

- Kosovo (Kosovo)

- Other:

2- Koji je Vaš spol? (What is your gender?) *

○ ženski (female)

○ muški (male)

- ne želim se izjasniti (I don't want to declare)

- drugo (Other)

3- Koliko imate godina? (What is your age?) *
○ $18-25$
○ 26-33
○ $34-41$
○ $42-49$
○ $50-57$
○ $58-65$
○ $65+$

4- Molimo odaberite Vašu razinu obrazovanja. (Please select your education level.) *

○ Osnovna škola (Elementary School)

- Srednja škola (Secondary School)

- Fakultetsko obrazovanje (University education)

- Poslijediplomsko obrazovanje (Post-graduate studies, Doctoral studies)

- Drugo (Other)

5- Koliki je vaš mjesečni prihod? (What is your monthly income?) *

- manje od 3250 kuna (less than 3250 kuna)

- 3250 kuna - 5000 kuna

- 5000 kuna - 7000 kuna

- 7000 kuna - 10000 kuna

- više od 10000 kuna

6- Molimo odaberite status vezan uz stanovanje koji najbolje opisuje Vašu situaciju. (Please select the status which best describes your living situation.) *

- S obitelji (With family)

- Sam / Sama (Alone)

- Drugo (Other)

7- Koji je Vaš bračni status? (What is your marital status?) *

- Neoženjen / Neudana (Single)

- Oženjen / Udana (Married)

- U vezi (In a relationship)

- Rastavljen / Rastavljena (Divorced)

- Udovac / Udovica (Widow)

- Drugo (Other) 
8- Odaberite status koji najbolje opisuje Vašu situaciju vezanu uz zaposlenje. (Please select your occupation status.) *

- Student/Studentica (Student)

- Nezaposlen / Nezaposlena (Unemployed)

- Umirovljen / Umirovljena (Retired)

- Zaposlen / Zaposlena u privatnom sektoru (Employed in the private sector)

- Zaposlen / Zaposlena u državnom sektoru (Employed in the state sector)

9- Koliko sati gledate televiziju u prosjeku radnim danom? (How many hours of television do you watch on average on a weekday?) *
- 0-2 sata (Hours)
- 2-5 sati (Hours)
- 5-10 sati (Hours)
○ 10-15 sati (Hours)
- 15-20 sati (Hours)
- 20-25 sati (Hours)

10- Koliko sati u prosjeku vikendom gledate televiziju? (How many hours of television do you watch on average on a weekend?) *
○ 0-2 sata (Hours)
- 2-5 sati (Hours)
- 5-10 sati (Hours)
- 10-15 sati (Hours)
- 15-20 sati (Hours)
- 20 sati (Hours) +

11- Koji žanr televizijskih serija gledate? (What kind of TV series do you watch?) *
$\checkmark$ Romantika (Romance)
$\checkmark$ Drama
$\checkmark$ Povijesni(Historical)
$\checkmark$ Za mladež (Youth)
$\checkmark$ Obitelj (Family)
$\checkmark$ Akcijski (Action)
$\checkmark$ Biografija (Biography)
$\checkmark$ Fantazija (Fantasy)
$\checkmark$ Znanstvena fantastika (Sci-Fi)
$\checkmark$ Horor (Horror)
$\checkmark$ Dokumentarni film (Documantary)
$\checkmark$ Triler (Thriller)
$\checkmark$ Mjuzikl(Musical)

12- Koji su elementi koji vas TV motiviraju da nastavite gledati? (What are the elements that tv series motivate you to keep watching?) *

$\checkmark$ Priča (Story)

$\checkmark$ Glumci i glumice (Actors\&Actresses)

$\checkmark$ Životni stil (Lifestyle)

$\checkmark$ Odjeća i modni dodaci (Clothing and Accessories)

$\checkmark$ Sadržaj (Content)

$\checkmark$ Gluma (Acting)

$\checkmark$ Zemlja porijekla serije (Country of origin of the TV show)

$\checkmark$ Arhitektura (Architectural Structures)

$\checkmark$ Jezik(Language)

$\checkmark$ Unutarnje ili vanjsko okruženje (Interior or Exterior Environment)

$\checkmark$ Glazba, glazbena podloga (Music-Soundtrack)

$\checkmark$ Montaža (Editing)

$\checkmark$ Drugo(Other) 
13- Gledate li turske TV serije? (Do you watch Turkish TV series (TTS)?) *

- Da (Yes)

- $\mathrm{Ne}(\mathrm{No})$

14- Gledate li turske TV serije samo na televiziji u redovnom programu ili ih gledate na internetu? (Do you watch Turkish TV series (TTS) only on television in regular program or you watch them on the internet?) *

- Samo televizija (Only television)

- Samo internet (Only internet)

○ Oboje (Both of them)

○ Drugo (Other)

15- Koliko ste turskih TV serija gledali u zadnjih 10 godina? (How many Turkish TV series (TTS) have you watched in the last 10 years?) *
○ $1-5$
○ $5-10$
○ $10-15$
○ 15-20
○ $20+$

16- Koju ste tursku TV seriju gledali? (Which Turkish TV series did you watch?) *

$\checkmark$ 1001. noć (Binbir Gece)

$\checkmark$ Strasti Orijenta (Aşk-ı Memnu)

$\checkmark$ Ezel (Ezel)

$\checkmark$ Gumuš (Gümüş)

$\checkmark$ Asi (Asi)

$\checkmark$ Bijeg (Menekşe ile Halil)

$\checkmark$ Kismet (Dudaktan Kalbe)

$\checkmark$ Moja majka (Annem)

$\checkmark$ Sjene prošlosti (Kaybolan Yillar)

$\checkmark$ Kad lišće pada (Yaprak Dökümü)

$\checkmark$ Ljubavi kazna (Aşk ve Ceza)

$\checkmark$ Sulejman Veličanstveni (Muhteşem Yüzyll)

$\checkmark$ Kako vrijeme prolazi (Öyle Bir Geçer Zaman ki)

$\checkmark$ Izgubljena čast (Fatmagül'ün Suçu Ne?)

$\checkmark$ Dila (Dila Hanım)

$\checkmark$ Nebo i zemlja (Kuzey Güney)

$\checkmark$ Da sam oblak (Bir Bulut Olsam)

$\checkmark$ Osveta (Intikam)

$\checkmark$ Milost (Merhamet)

$\checkmark$ Ne brini za mene (Benim İçin Üzülme)

$\checkmark$ Crna ruža (Karagül)

$\checkmark$ Časni ljudi (Karadayl)

$\checkmark$ Ljubav i novac (Kara Para Aşk)

$\checkmark$ Sudbina (Kaderimin Yazıldlğı Gün)

$\checkmark$ Plima i oseka (Medcezir)

$\checkmark$ Pitanje časti (Fatih Harbiye)

$\checkmark$ Ranjena ljubav (Vatanim Sensin)

$\checkmark$ Ponovno rođen (Kış Güneşi)

$\checkmark$ Anđeli (Kırgıı Çiçekler)

$\checkmark$ Kraljica noći (Gecenin Kraliçesi)

$\checkmark$ Obitelj mog oca (Babam ve Ailesi)

$\checkmark$ Nauči me voljeti (Bana Sevmeyi Anlat)

$\checkmark$ Bit ćeš moja (Kara Sevda)

$\checkmark$ Ukradeni život (Kaylp) 


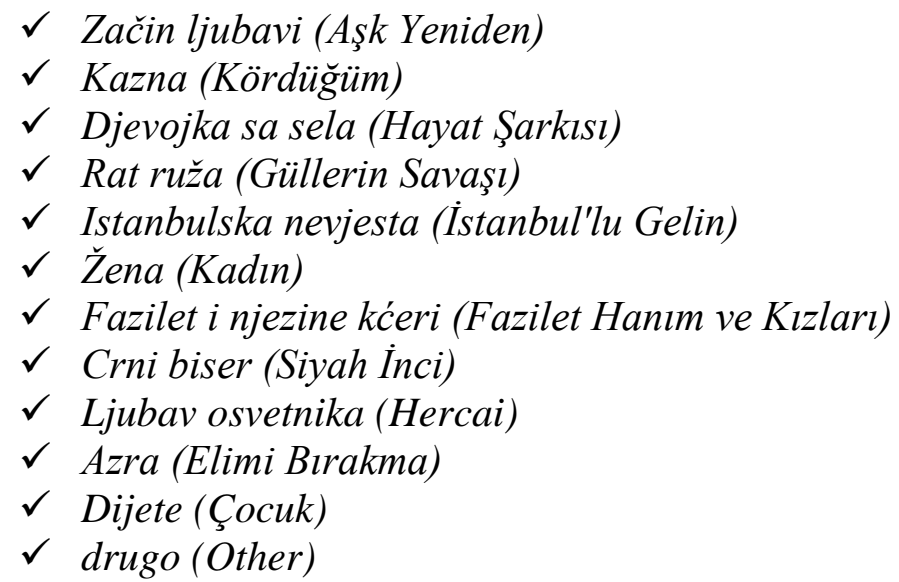

17- Koje je Vaše mišljenje o kvaliteti turskih serija? (What is your opinion on the quality of Turkish TV series (TTS)?) *
- Vrlo dobro (Very Good)
- Dobro (Good)
- Srednje (Not good, not bad)
- Loše (Bad)
- Jako loše (Very Bad)

18- Koji su elementi koje vas turska TV serija (TTS) motivira da nastavite gledati? (What are the elements that Turkish tv series (TTS) motivate you to keep watching?) *

$\checkmark$ Priča (Story)

$\checkmark$ Glumci i glumice (Actors\&Actresses)

$\checkmark$ Životni stil (Lifestyle)

$\checkmark$ Odjeća i modni dodaci (Clothing and Accessories)

$\checkmark$ Sadržaj (Content)

$\checkmark$ Gluma (Acting)

$\checkmark$ Zemlja porijekla serije (Country of origin of the TV show)

$\checkmark$ Arhitektonske građevine (Architectural Structures)

$\checkmark$ Jezik(Language)

$\checkmark$ Unutarnje ili vanjsko okruženje (Interior or Exterior Environment)

$\checkmark$ Glazba i glazbena podloga (Music-Soundtrack)

$\checkmark$ Montaža (Editing)

$\checkmark$ Drugo (Other)

19- Postoje li druge turske TV serije koje gledate putem interneta, osim onih koje se prikazuju na televiziji? (Are there any other Turkish TV series that you watch over the internet, other than released on TV?) *

○ Da (Yes)

○ $\mathrm{Ne}(\mathrm{No})$

20- Koliko turskih TV serija pratite na Internetu, osim onih objavljenih na tv-u? (How many Turkish TV series you follow on the Internet, other than released on TV?) *

Nijednu (None)
○ $1-3$
○ 4-6
○ $7-10$
○ $10+$

21- Koje još TV serije gledate na internetu, osim onih koje objavljuju na televiziji? (What other TV series are you watching on the internet other than released on television?)

- Your answer

22- Koje TV serije najradije gledate? (Which region's TV series do you prefer to watch?) *

$\checkmark$ Domaće serije (Domestic)

$\checkmark$ Turske(Turkish)

$\checkmark$ Američke (American) 
$\checkmark$ Latinoameričke (Latino American)

$\checkmark$ Europske (European)

23- Želite li što dodati? (Is there anything you want to add?)

- Your answer 